\title{
Advanced wastewater treatment stage for textile industry
}

\section{REZUMAT - ABSTRACT}

\section{Etapa avansată de tratare a apelor reziduale pentru industria textilă}

Flotația cu aer dizolvat reprezintă o etapă importantă pentru tratarea apelor reziduale și a fost utilizată în ultimii șaizeci de ani pentru diferiți poluanți cum ar fi: solide în suspensie, grăsimi, uleiuri etc. În prezent, sistemele cu aer dizolvat sunt în general aplicate în stațiile de tratare a apelor reziduale industriale, acolo unde cantitatea de poluanți este mai mare decât media (industria textilă și pielărie). Membrii echipei de cercetare au dezvoltat o unitate inovatoare DAF și au realizat un demonstrator experimental de laborator. A fost testată instalația în laborator și a fost demonstrată eficiența tratării apelor reziduale. Ultimele cercetări au demonstrat că reactivii de flotație au un rol esențial în eliminarea diferiților poluanți. Literatura științifică demonstrează că acești reactivi pot fi utilizați pentru a elimina poluanții precum nămolul sau spuma. Reactivii sunt clasificați în modificatori, floculanți, depresante, colectori și agenți de spumare, în funcție de rolul lor în procesul de flotație. Utilizarea nanomaterialelor în tratarea apelor reziduale a devenit un subiect intens studiat. Reactivii colectori, pe bază de nanoparticule hidrofobe, pot absorbi o cantitate mai mare de poluanți datorită suprafețelor cu particule hidrofile care facilitează atașarea poluanților de bulele de aer generate de unitatea DAF. În studiul de față, cercetătorii susțin că rolul nanoparticulelor este de a facilita atașarea bule-particule și/sau de a minimiza detașarea. Scopul studiului este de a lua în considerare influența parametrilor nanoparticulelor asupra diferitelor etape ale flotației particulelor pentru a demonstra rolul-cheie al nanoparticulelor în eliminarea poluanților din apele reziduale din industria textilă.

Cuvinte-cheie: unitate de flotație cu aer dizolvat (DAF), tratarea apelor reziduale, nanomaterial, sedimentator

\section{Advanced wastewater treatment stage for textile industry}

Dissolved air flotation represents an important stage for wastewater treatment and was used during the last sixty years for different pollutants such as: suspended solids, greases, oils etc. Nowadays, the dissolved air systems are generally applied in industrial wastewater treatment plants, where the amount of pollutants is above the average (textile and leather industry). The research team members developed an innovative DAF unit and realized a laboratory demonstrator (figure 1). The laboratory installation was tested and the efficiency of wastewater treatment was demonstrated. The latest researches proved that flotation reagents have an essential role in the removal of different pollutants. The scientific literature demonstrates that these reagents can be used to remove the pollutants as sludge or foam, Reagents are divided into modifiers, flocculants, depressants, collectors and frothers, depending on their role the flotation process. Nanomaterial utilization in wastewater treatment has become an intensely studied topic. Collectors reagents, based on hydrophobic nanoparticles, can adsorb a larger quantity of pollutants due to the hydrophilic particle surfaces that facilitate the attachment of pollutants to air bubbles generated by the DAF unit. In the present paper, the researchers present that the role of nanoparticles is to facilitate particle-bubble attachment and/or to minimize detachment. The goal of the study is to consider the influence of nanoparticle parameters on the various stages of particle flotation to demonstrate the key role of nanoparticles in removal of pollutants from textile wastewaters.

Keywords: dissolved flotation unit (DAF), wastewater treatment, nanomaterial, settler

\section{INTRODUCTION}

Textile industry requires important quantities of water, and accordingly produces important quantities of wastewaters with high quantities of different pollutants. Depending on the textile finishing procedures the discharged wastewaters may contain: organic substances $\left(\mathrm{COD}, \mathrm{BOD}_{5}\right)$, dissolved organic agents, surfactants, halogenated organic compounds, heavy metals, dyes, sulphates, suspended solids, etc. The biological compounds can be biologically removed from wastewater, if the largely lacking nutrients (nitrogen and phosphorous) are supplementary added [1]. Textile wastewater treatment requirements vary, accordingly to the quantities of textiles that are finished and the technological processes inside the textile factories. Due to the large diversity of the finishing processes and factories, the wastewater quality is determined for each application. In general, the textile discharged wastewaters are treated in local wastewater treatment plants (WWTPs), managed by the textile companies, or in some cases are treated in municipal WWTPs. In the cases of direct discharge into a receiving water, process combinations consisting of the following process steps have proven to be successful. The minimum wastewater treatment processes for the textile production and finishing include: mechanical wastewater pre-treatment; storage and homogenization; flotation; $\mathrm{pH}$ neutralization; chemical precipitation; biological (aerobic and anoxic) treatment; process automation. 
Dissolved air flotation (DAF) is an effective technology for treating a variety of wastewaters including the ones discharged from the textile industry [2]. DAF systems are used for the removal of suspended solids including fibers, greases, oils. Due to oxygen presence in wastewater tanks, other types of pollutants can be removed.

DAF is a two-step process, the first being the pretreatment process and the second being a flotation process [3]. During the pre-treatment process, chemicals are introduced within the wastewater to create light, floatable flocs in the tanks. After pre-treatment process, air bubbles are introduced into the reactors. The air bubbles will float the flocs, so the pollutants are rising to the water surface from where are separated with the help of a skimmer.

\section{UTILIZATION OF DISSOLVED AIR FLOTATION IN TEXTILE INDUSTRY}

Dissolved air flotation is used for the removal of a wide range of pollutants and can be highly efficient if an uniform distribution of air bubbles is realised. The research team proposes a DAF unit for textile industry. conditions, the dissolved air inside the water mass is transformed into micro air bubbles (20-100 microns). The air-water mixture is discharged inside a lamellar settler. The formed flocs are rising to the water surface and are removed with the help of a skimmer.

The DAF efficiency is dependent on the detention time and the contact surface area inside the capsule. The contact area can be increased by a very fine dispersion of the water and by small air bubbles inside the capsule. In this respect, the research team has made ample research on both air and water inlets. Figure 2, $A$ presents the patented capsule [4] that was already tested for the wastewater treatment. The body of capsule has a cylindrical shape with 2 caps. Inside the pressure capsule water and air are introduced. The water feeding is located at the upper part of the capsule where treated/clean water is introduced through four sprinklers. So, the capsule is fed with very fine dispersed water drops and not with water jet. The air is introduced at the lower of the capsule. The air diffuser inside the capsule consists in a stainless-steel pipe with $1 \mathrm{~mm}$ apertures to introduce the air is small bubbles. In this way the contact

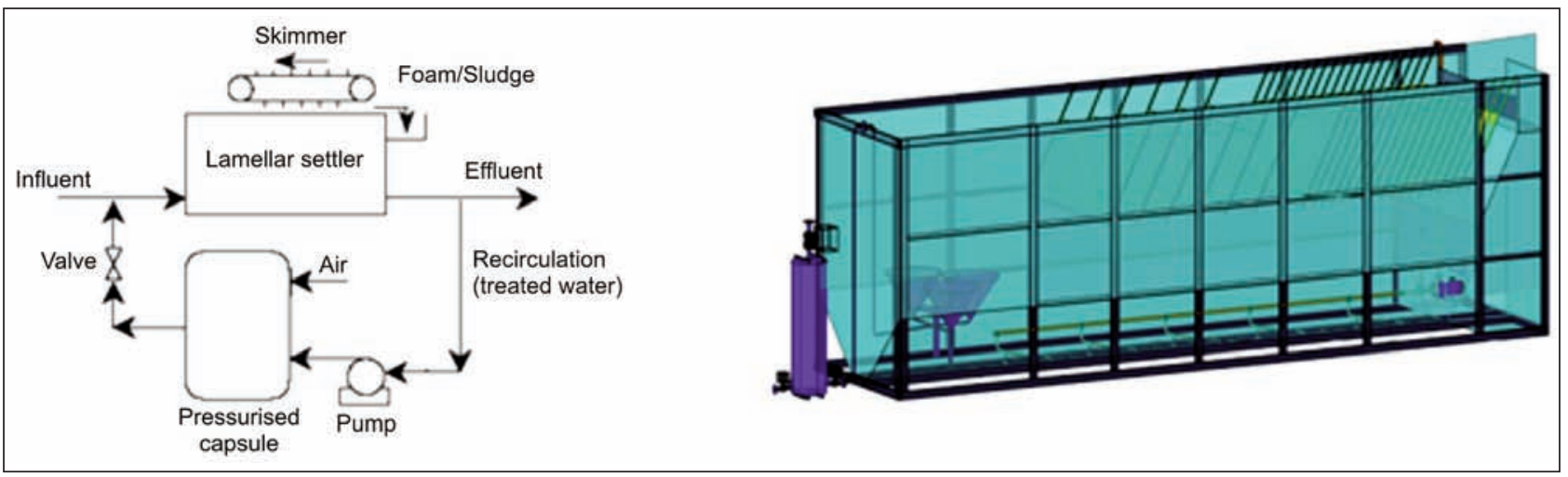

Fig. 1. Dissolved air flotation stage used in textile industry

The main components of the DAF technology consist in: a pressure capsule, a lamellar settler, a dosing system with nanomaterials for an increased pollutant removal efficiency (figure 1). The pressured capsule is feed with treated water and air. A pressure of 5 bar is created inside the capsule. The introduced air, under the pressure, is dissolved inside the water mass. This stage is followed by a depression to the atmospheric pressure. During the depression

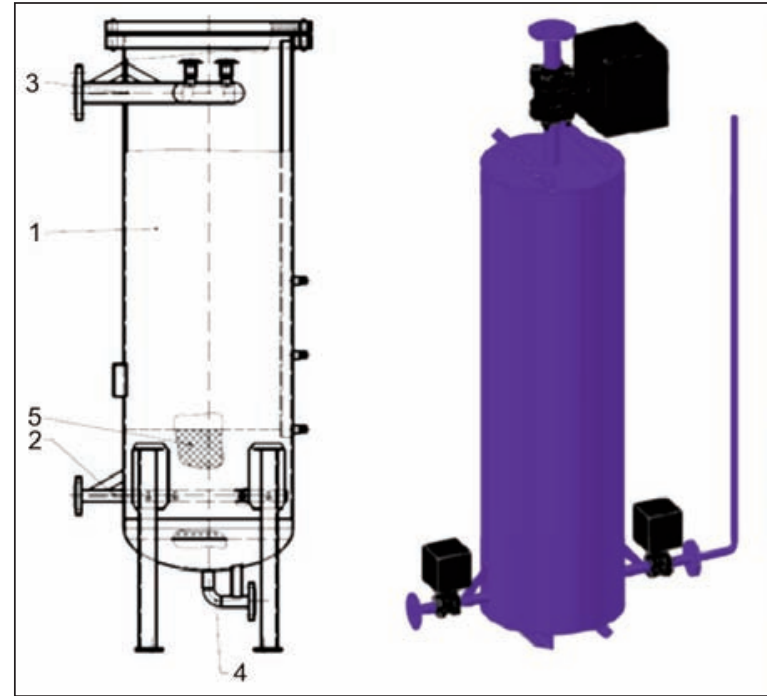

A

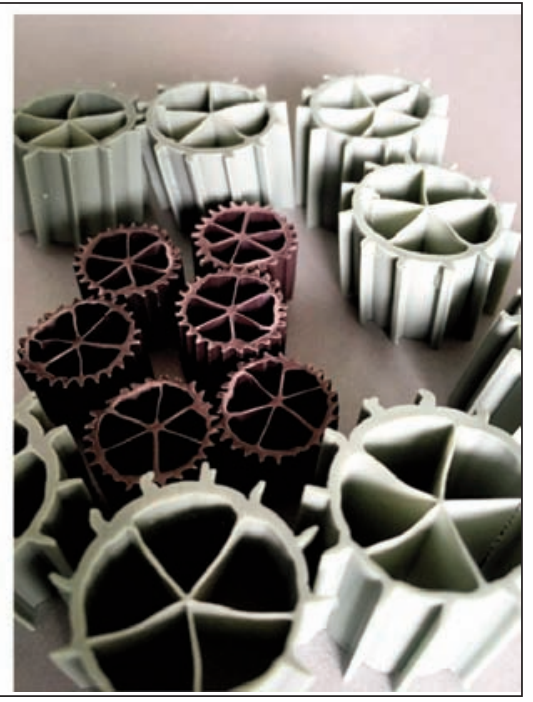

B

Fig. 2. Innovative pressure capsule proposed by the researchers:

A. 1 - pressure capsule; 2 - air inlet; 3 - water inlet; 4 - pressured water with dissolved air outlet; 5 - filling (small moving plastic elements, as shown in B); B. biofilm carriers inside the capsule 
surface between air and water is maximized. To obtain a longer time contact between the air bubbles and water, the researchers introduced small plastic elements (figure 2, $B$ ) inside the capsule. This patented solution assures a better efficiency of small air bubble generation inside the lamellar settler.

\section{LAMELLAR SETTER DESIGNING}

Mathematical modelling processes and numerical simulations are starting to have a higher importance in the designing phase of various types of equipment. Using this tool, investors will save money and time. In addition to engineering design calculations, numerical simulations have become a necessary activity in design. In the present study, the optimal shape for a lamellar clarifier was determined with the help of numerical simulations. The lamellar settles have an increased efficiency in settling solid suspensions relative to conventional longitudinal clarifiers.

In literature it is mentioned that for the sedimentation of granular particles, the low depth basins are economically preferable. These considerations have led to the emergence of lamellar decanters. The lamellar settler is highly efficient and does not require a very large space for the solid suspensions sedimentation. For such a lamellar clarifier, a series of mathematical modelling and numerical simulations were performed, as follows. These numerical simulations were necessary to avoid the preferential flows and currents inside the clarifier. To efficiently design the lamellar decanter, several types of lamellar decanters (with different dimensions, configurations and lengths of decanter plates) were analysed. Primarily, a decanter with a length of $2,000 \mathrm{~mm}$, a useful height of 2,600 $\mathrm{mm}$ and a width of $3,000 \mathrm{~mm}$ was considered. A solid suspension concentration of $300 \mathrm{mg} / \mathrm{l}$ was also considered. The decanter plate package has a length of $1,500 \mathrm{~mm}$ (figure 3).

The discharge of the treated water outside the settler is performed at the top, i.e. the upper right corner of the images. It is noted that the lamellar settler provides high efficiency for the sedimentation process, yielding approximately $30 \mathrm{mg} / \mathrm{l}$ of solid suspensions. Forward the length of the decanter plates has been changed, and the results are shown in figure 4.

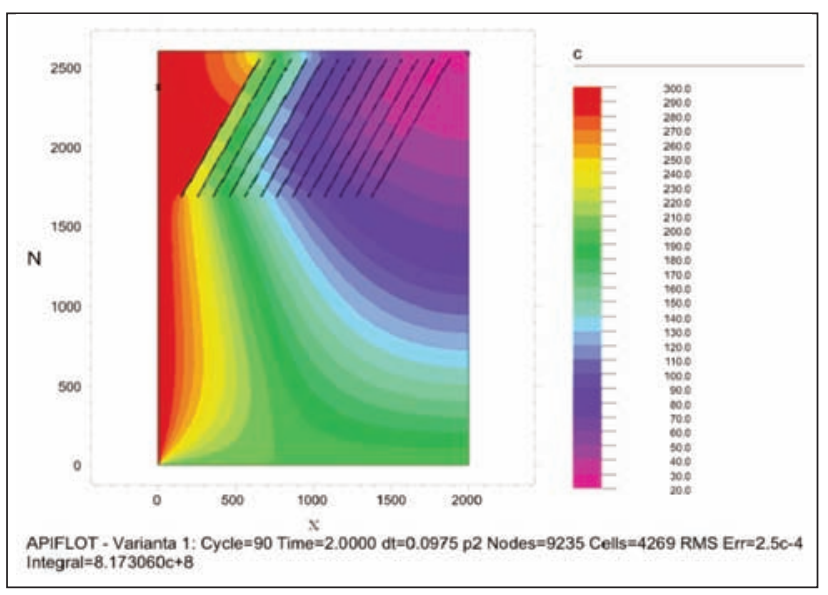

Fig. 3. Lamellar settler - variant 1. Sedimentation of solid suspensions

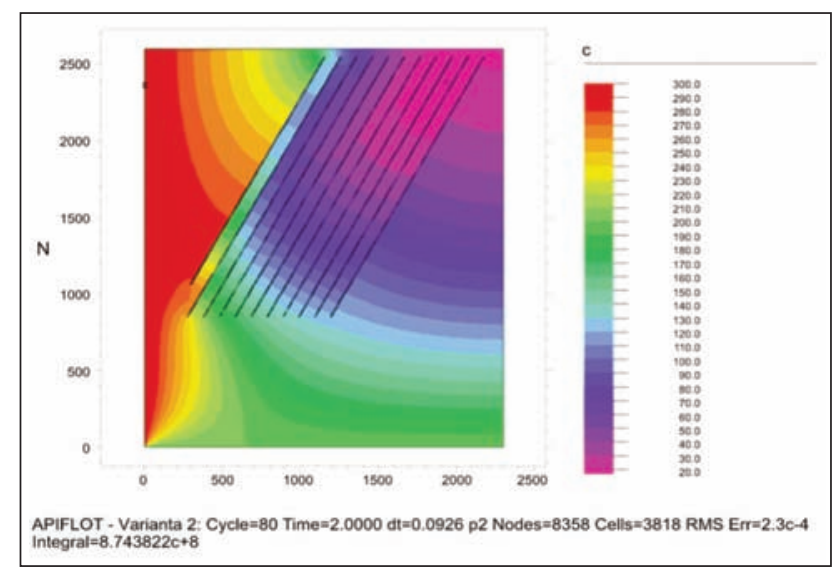

Fig. 4. Lamellar settler - variant 2. Sedimentation of solid suspensions

In comparison with the above-mentioned case, an improvement in the decanter efficiency is observed, which is in line with the results obtained by other researchers - increasing the length of the decanting plates provides greater efficiency. In the third option different lengths of decanting plates are considered (figure 5). As it can be seen in this case, the lamellar decanter is well-sized. The next step was increasing the number of decanter plates and the length of the decanter to $3,000 \mathrm{~mm}$ (figure 6).

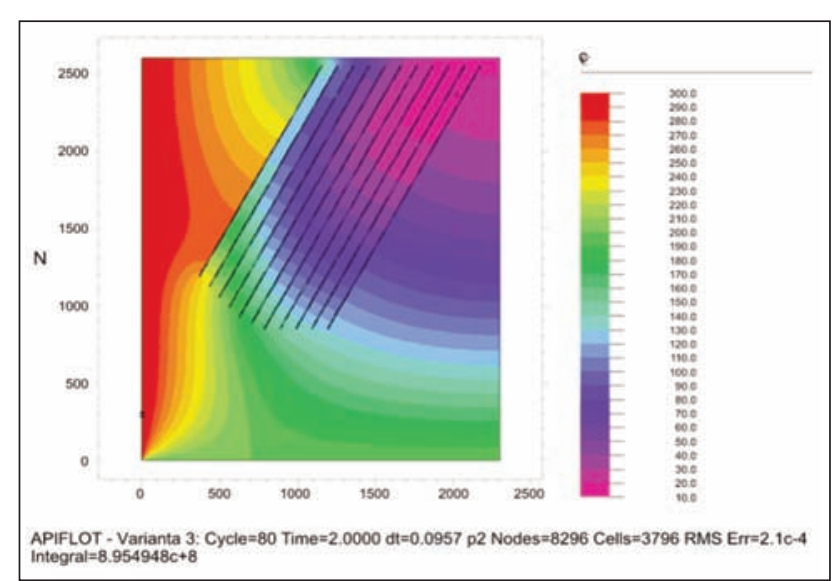

Fig. 5: Lamellar settler - variant 3. Sedimentation of solid suspensions

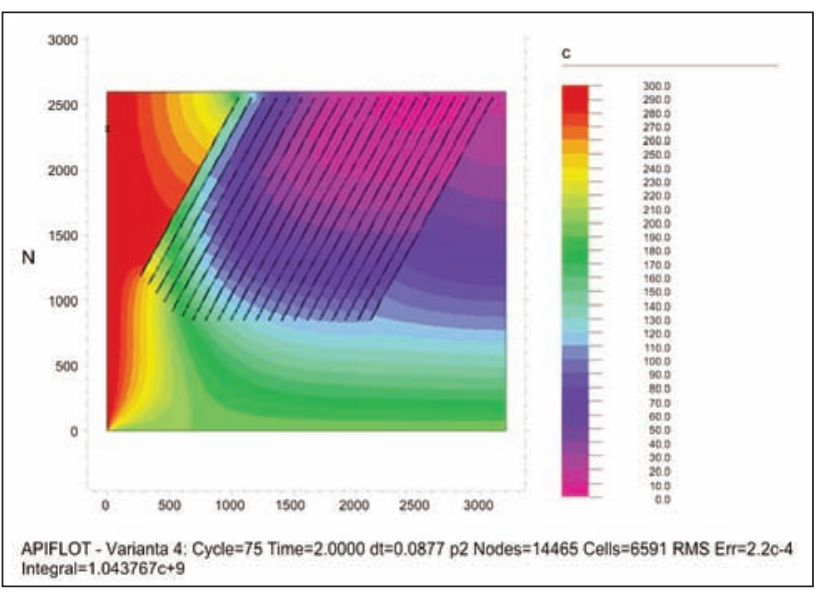

Fig. 6: Lamellar settler - variant 4. Sedimentation of solid suspensions 


\section{IMPROVEMENT OF THE DISSOLVED AIR FLOTATION SYSTEM}

The treatment efficiency for the above presented DAF unit can be improved by adding a nanoparticle dosing system [5]. The nanoparticle introduced in DAF will have the role of stabilizing the foam. In this way more stable foam will be formed and evacuated from the system. The purpose of the dosing system is to allow a good dispersion of nanoparticles used as flotation agents in scrubbed wastewater. The component elements of the flotation agents dosing system are: metering pump; water tank with suspension particles; pipes; diffusion system inside the lamellar settler [6].

The flotation agents will be introduced in the tank where they will be uniformly incorporated in the water through the stirring system. From there, the floatation agents will be transported using a metering pump to the lamellar clarifier from where they will be injected into the residual water via the diffusion system. There they will adhere to colloidal particles or fat and froth. The foam will be collected so that through the particle recuperator, the flotation agents are recovered. Recovery further envisages the application of some methods for the regeneration of flotation agents from nanomaterials class. The metering pump will be protected from idle running with a float switch. The system diagram is presented in figure 7.

For example, for the purpose of separating/recovering valuable or pollutant particles (e.g. minerals), the flotation process is of particular importance. In the physico-chemical flotation process, the collector selectively binds the particles, increasing their hipprophobicity and thus promoting the attachment of particles to the air microbubbles [7].

Conventional collectors are low molecular weight surface active agents that promote adsorption on mineral surfaces [7]. According to Songtao Yang (2011) conventional water-soluble collectors can be partially or completely replaced by nanoparticulate hydrophobic colloidal collectors [7]. Songtao Yang et al. (2011) published the first report describing a new technology in which hydrophobic nanoparticles adsorb on much larger surfaces the hydrophilic mineral particles to improve the adsorption process at air bubble level. Songtao Yang et all. (2011) prepared by standard emulsion polymerization technique a series of nanoparticle suspensions, resulting in spherical particles with a very narrow dimensional distribution [8]. The major component of the nanoparticles was polystyrene, a rather hydrophobic plastic.

Nanoparticle collectors are likely to influence two important steps in the flotation mechanism: the adsorption of the beads to be separated from the water on the surface of the air bubble after collision and the desorption of unwanted particles from the surface of the bubble.

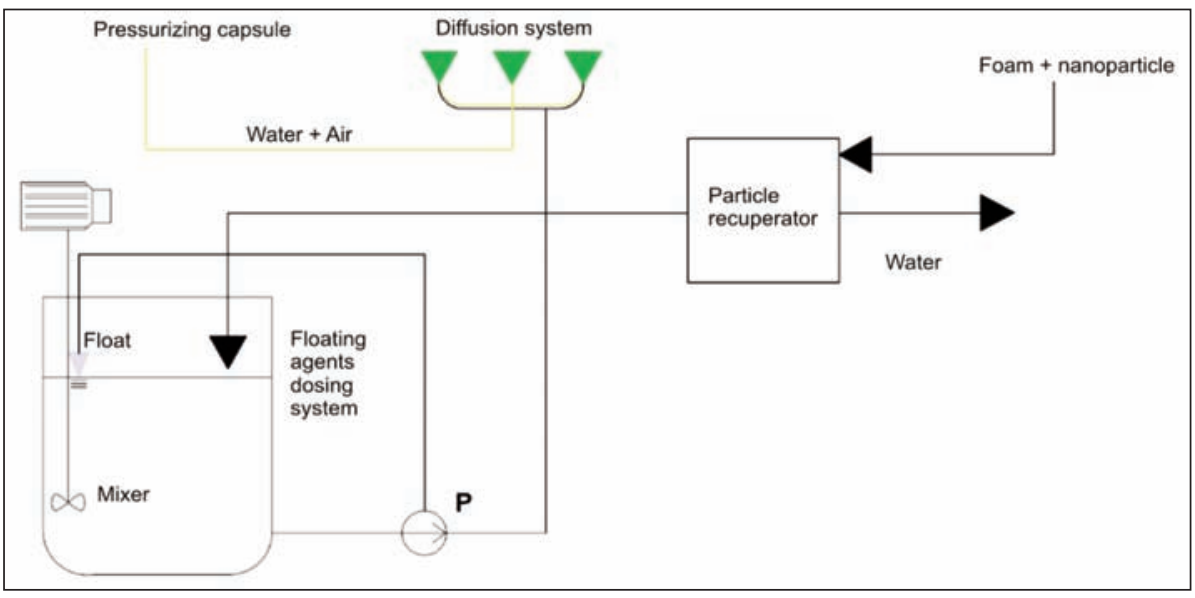

Fig. 7: Basic diagram for the flotation agents metering system

Understanding the mechanism by which nanoparticles make flotation more efficient is important because it is possible to find out what the role of nanoparticle size is in flotation.

A new idea for improving the process of flotation is introducing nanoparticles of inorganic nature (e.g. $\mathrm{TiO}_{2}, \mathrm{SiO}_{2}$, $\mathrm{Al}_{2} \mathrm{O}_{3}$, etc.) or organic (e.g. polystyrene etc.), which can increase the efficiency of wastewater pollutants removal. The role of nanoparticles in the flotation installation is to

\section{TYPES OF FLOTATION AGENTS THAT ARE USED IN DAF SYTEMS}

The need to achieve a high efficiency in wastewater treatment, corroborated with environmental compliance, requires finding ways to improve and streamline the flotation process applied to heavily loaded waters. Flotation is a prerequisite for the purification of this type of highly loaded water intended to be purged within the system to be achieved in the present project.

The purpose of testing new types of nanoparticle collectors has been generated by finding new methods of removing and recovering materials-compounds which are found in a extremely low concentration in the water. obtain high yields in removing organic pollutants from water, such as fats, dyes, oils, animal or vegetable waste.

Therefore, the following types of inorganic nanoparticles will be used for the purpose of flotation efficiency: $\mathrm{SiO}_{2}, \mathrm{TiO}_{2}, \mathrm{Fe}_{2} \mathrm{O}_{3}$ and $\mathrm{Al}_{2} \mathrm{O}_{3}$ which have already shown encouraging results in the flotation process, table 1 [9]. In the experiments to be performed, there will be tested $0.25 \mathrm{~g} / \mathrm{l}$ of nanomaterial. By using the nanomaterials in the flotation process the following results are achieved: an increase in foam thickness and greater stability of micro-bubbles.

Particles of nanometric size stabilize the foam creating a barrier between the air bubbles so that they do not merge [10]. 
In case of usage in the flotation steps, a system for removing the foam that forms on the free surface of the water will be required. In this way, a highly efficient wastewater treatment system will be developed to treat highly charged wastewater.

A new idea of improving the flotation process is the introduction into the equipment by means of a dosing system for flotation agents represented by nanoparticles of inorganic nature (ex. $\mathrm{Al}_{2} \mathrm{O}_{3}, \mathrm{SiO}_{2}, \mathrm{TiO}_{2}$, etc.) or organic (ex. polystyrene etc.), which can increase the pollutant removal efficiency from the discharged wastewaters. The role of nanoparticles in the flotation process is to obtain high yields for removing organic pollutants from water, such as fats, colloidal particles, dyes, oils, animal or vegetable waste as well for removing fine suspended solids in general.

\section{AKNOLEDGEMENTS}

This work was supported by a grant of the Romanian National Authority for Scientific Research and Innovation, CNCS/CCCDI - UEFISCDI, project number PN-III-P2-2.1PTE-2016-0183 (APIFLOT-II), within PNCDI III.

\section{BIBLIOGRAPHY}

[1] Metcalf and Eddy, Inc., Wastewater engineering: Treatment and reuse, fourth edition. In: McGraw-Hill Handbooks, New York, USA (2003).

[2] Sarbu, R., Badulescu, C., Toth, L. Wastewater treatment by flotation, In: Acta Montanistica Slovaca, 2005, no. 1, pp. 97-99.

[3] American Water Works Association, Water quality and treatment, A Handbook of Community Water Supplies, In: McGraw-Hill Handbooks, New York, USA (2000).

[4] Petrescu, G., Nasarimba-Grecescu, B.D., Moga, I.C., RO Patent no. 126396.

[5] Cilek, E.C., Karaca, S. Effect of nanoparticles on froth stability and bubble size distribution in flotation, In: International Journal of Mineral Processing, 2015, no. 138, pp. 6-14.

[6] ***, Technical reports for APIFLOT-II project, 2016.

[7] Yang, S. Nanoparticle flotation collectors, Jilin University, 2011.

[8] Yang, S., Pelton, R. Nanoparticle flotation collectors II: The role of nanoparticle hydrophobicity, McMaster University, 1280 Main Street West, Hamilton, Ontario, Canada, 2011

[9] Emin, C.C., Sevgi, K. Effect of nanoparticles on froth stability and bubble size distribution in flotation, In: International Journal of Mineral Processing 2015, no. 138.

[10] Dong, X., Marway, H.S., Cranston, E.D., Pelton, R.H. Relating nanoparticle shape and adhesiveness to performance as flotation collectors, Department of Chemical Engineering, McMaster University, 1280 Main Street West, Hamilton, Ontario, Canada, 2016.

\section{Authors: \\ IOANA CORINA MOGA ${ }^{1}$ \\ MIHAI GABRIEL MATACHE ${ }^{2}$ \\ ILEANA CRISTINA COVALIU ${ }^{3}$}

${ }^{1}$ Department of Research and Development, DFR Systems SRL, Bucharest, Romania

${ }^{2}$ Testing Department, National Institute of Research-Development for Machines and Installations Designed to Agriculture and Food Industry, Bucharest, Romania

${ }^{3}$ Department of Biotechnical Systems, University Politehnica of Bucharest, Bucharest, Romania

Corresponding author:

IOANA CORINA MOGA

e-mail: corinamoga@yahoo.com 